\title{
Neural network based thermal protective performance prediction of three-layered fabrics for firefighter clothing
}

Predicția performanței de protecție termică pe baza rețelei neurale a țesăturilor cu trei straturi pentru îmbrăcămintea pentru pompieri

Îmbrăcămintea de protecție pentru pompieri este compusă din trei straturi principale; un strat exterior, o barieră împotriva umezelii și o căptușeală de izolație termică. Această structură de țesături cu trei straturi asigură protecție împotriva incendiilor și mediilor cu temperatură foarte ridicată. Diverși parametri, cum ar fi construcția țesăturii, greutatea, desimea în urzeală/bătătură, grosimea, rezistența la vapori de apă a straturilor de material textil, au efect asupra performanței de protecție, cum ar fi transferul de căldură prin îmbrăcămintea de protecție pentru pompieri. Obiectivul acestui studiu este examinarea predictibilității indicelui de transfer de căldură al țesăturilor cu trei straturi, ca funcție a parametrilor țesăturii, prin utilizarea rețelelor neurale artificiale. Prın urmare, s-au obținut 64 combinații diferite de țesături cu trei straturi pentru îmbrăcămintea de protecție pentru pompieri, iar transferul de căldură prin convecție (HTI) și transferul de căldură radiant (RHTI), prin combinațiile de țesături, au fost măsurate în laborator. Șase rețele neurale cu perceptron multiplu (MLPNN), fiecare cu un singur strat ascuns și aceleași 12 date de intrare, au fost construite separat pentru predicția performanței transferului de căldură prin convecție și a performanței transferului de căldură radiant a țesăturilor cu trei straturi. Rețelele 1-4 au fost instruite pentru predicția $\mathrm{HTI}_{12}, \mathrm{HTI}_{24}, \mathrm{RHTI}_{12}$ și, $_{\text {, }}$ respectiv, $\mathrm{RHTI}_{24}$, în timp ce rețelele 5 și 6 au avut două ieșiri, respectiv $\mathrm{HTI}_{12}$ și $\mathrm{HTI}_{24}$, respectiv $\mathrm{RHTI}_{12}$ și $\mathrm{RHTI} \mathrm{H}_{24}$. Fiecare sistem indică o bună corelare între valorile estimate și valorile experimentale. Rezultatele demonstrează că MLPNN-urile propuse sunt capabile să estimeze transferul de căldură prin convecție și transferul de căldură radiant eficient. Cu toate acestea, rețeaua neurală cu două ieșiri are o performanță de predicție ușor mai bună.

Cuvinte-cheie: rețele neurale artificiale, predicție, transfer de căldură, țesături cu trei straturi, îmbrăcăminte de protecție pentru pompieri

\section{Neural network based thermal protective performance prediction of three-layered fabrics for firefighter clothing}

The firefighter protective clothing is comprised of three main layers; an outer shell, a moisture barrier and a thermal liner. This three-layered fabric structure provides protection against the fire and extremely hot environments. Various parameters such as fabric construction, weight, warp/weft count, warp/weft density, thickness, water vapour resistance of the fabric layers have effect on the protective performance as heat transfer through the firefighter clothing. In this study, it is aimed to examine the predictability of the heat transfer index of three-layered fabrics, as function of the fabric parameters using artificial neural networks. Therefore, 64 different three layered-fabric assembly combinations of the firefighter clothing were obtained and the convective heat transfer (HTI) and radiant heat transfer (RHTI) through the fabric combinations were measured in a laboratory. Six multilayer perceptron neural networks (MLPNN) each with a single hidden layer and the same 12 input data were constructed to predict the convective heat transfer performance and the radiant heat transfer performance of three-layered fabrics separately. The networks 1 to 4 were trained to predict $\mathrm{HTI}_{12}, \mathrm{HTI}_{24}, \mathrm{RHTI}_{12}$, and $\mathrm{RHTI}_{24}$, respectively, while networks 5 and 6 had two outputs, $\mathrm{HTI}_{12}$ and $\mathrm{HTI}_{24}$, and $\mathrm{RHTI}_{12}$ and $\mathrm{RHTI}_{24}$, respectively. Each system indicates a good correlation between the predicted values and the experimental values. The results demonstrate that the proposed MLPNNs are able to predict the convective heat transfer and the radiant heat transfer effectively. However, the neural network with two outputs has slightly better prediction performance.

Keywords: artificial neural networks, prediction, heat transfer, three-layered fabrics, firefighter protective clothing

\section{INTRODUCTION}

Firefighters are subjected to various fire conditions and extreme thermal environments. Protective clothing provides protection from the thermal hazards, and allows firefighters to work effectively in dangerous thermal environments. This clothing comprises three fabric layers; an outer shell fabric, a moisture barrier, and a thermal liner [1]. The thermal protection of the fabrics is influenced by various properties of these three layers: weight, thickness, construction, water vapour permeability etc. These fabric characteristics are related to each other, and are nonlinear with the thermal protection properties.

Many studies investigated the performance of thermal protective fabrics with the structural features under the laboratory simulated thermal exposures $[1,2-7]$. However, it is time consuming and costly to experiment with different fabric characteristics and to evaluate the relation with protective performance. 
Moreover, because it is difficult to take account of all fabric parameters simultaneously, and to investigate the effects on the thermal protection performance of three layered fabrics, a new system is required for the effective prediction of the protective performance of such fabrics. An artificial neural network (ANN) is a computational structure and can be used to model the non-linear problems and predict the output values for given input parameters [8, 9]. In this respect, an ANN can be effectively used to evaluate the collective influence of all fabric parameters on the thermal protective performance.

ANN is applied in many field of textile industry such as prediction of yarn and fabric properties, defect detection of textile products, quality control, prediction in garment industry, identification and classification of different textile properties [9-17]. Because many prediction-related problems and textile processes are non-linear, ANNs are considered suitable. Several researchers have investigated on the prediction of the thermal resistance and the thermal performance of the textile fabricsusing artificial neural networks. Bhattacharjee \& Kothari used ANN to predict the steady-state thermal resistance and maximum instantaneous heat transfer $Q_{\max }$ of a fabric, when the fabric weaving and construction parameters are used as inputs [18]. Cui and Zhang investigated the use of artificial neural networks to predict the thermal protective performance of fabrics [19]. In all these studies, an ANN was used to predict the thermal properties of single layer fabrics.

In the literature, there has been no study regarding the prediction of thermal protective performance of three-layered fabrics used for the firefighter protective clothing. In this study, it is aimed to design an artificial neural network to predict the thermal protective performance of three-layered fabrics. Therefore, six artificial neural networks were constructed to predict the convective heat transfer and the radiant heat transfer of three layered fabrics separately. Four samples from each of outer shell, moisture barrier and thermal liners were selected to create 64 different three-layered fabric assemblies. Six MLPNN were separately trained and tested in a supervised manner, with 12 input fabric characteristics and two actual output experiment values were obtained from the heat transfer instruments. All MLPNNs had the same 12 input fabric characteristics, but a different number of outputs. The outputs of networks were $\mathrm{HTI}_{12}$ and $\mathrm{HTI}_{24}$ for EN 367 standard and $\mathrm{RHTI}_{12}$ and $\mathrm{RHTI}_{24}$ for EN ISO 6942 standard. The heat transfer index values were obtained from the trained networks and the results were compared with the actual experimental values captured from the heat transfer instruments.

\section{MATERIALS AND METHODS}

Fabric samples and parameters

Four outer shell fabrics, four moisture fabrics and four thermal liners were chosen to represent various combinations of firefighter protective clothing for the performance evaluation of the artificial neural networks. The outer shells are made of Nomex, Polybenzimidazole (PBI) and Kevlar. The moisture barriers are made of polyurethane laminated flame retardant (FR) fabrics. The thermal liners are made of a FR woven fabric quilted to the FR nonwoven or FR felt. The parameters; weave, warp count, weft count, warp density, weft density, weight, thickness, and Limiting oxygen index (LOI) for the outer shell; the weight, thickness and water vapor resistance for the moisture barrier; weight and thickness for the thermal liner were selected to have as ANN inputs. These fabric parameters are related to the thermal protective performance. The warp count and weft count of the outer shells were measured in accordance with standard TS 255. The warp and weft density of the outer shells were measured in accordance with TS 250 EN 1049-2. The thickness of the fabrics was measured pursuant to standard TS 7128 EN ISO 5084 and the weight of the fabrics was measured pursuant to TS 251. The LOI test results values of the outer shells were obtained in accordance with ASTM $\mathrm{D}$-2863. The water vapour resistance of the moisture barriers was obtained from an accredited testing laboratory.

\section{Test methods}

To measure thermal protective performance of threelayered fabrics, 64 samples were obtained from combinations of four different outer shells, four different moisture barriers and four different thermal liners. The thermal protective performance of a protective clothing system is related to the radiant and convective heat transfer properties through the fabric layers. In this study, convective heat transfer and radiant heat transfer were measured separately.

\section{Measurement of the convective heat transfer (Heat transfer-flame)}

The convective heat transfer can be assessed in respect to Standards No. EN 367 "Protective clothing protection against heat and fire-Method of determining heat transmission on exposure to flame" [20]. The test method in the standard provides thermal performance measures of the component fabrics and therefore, heat transfer within the garment. Figure 1 shows the heat transfer flame tester used during the tests.

The heat protection characteristics of the fabrics are determined by measuring the time to reach a temperature increase of $12^{\circ} \mathrm{C}$ or $24^{\circ} \mathrm{C}$ in a calorimeter $\left(t_{12}\right.$ and $t_{24}$, respectively) covered with the samples when exposed to a convective heat source of 80 $\mathrm{kW} / \mathrm{m}^{2}$ [21]. It is used to measure the time to theoretical pain and second-degree burn through fabric ensembles. These two time values indicate the performance level of the fabrics and are defined as heat transfer index $\left(\mathrm{HTI}_{12}, \mathrm{HTI}_{24}\right)$. 


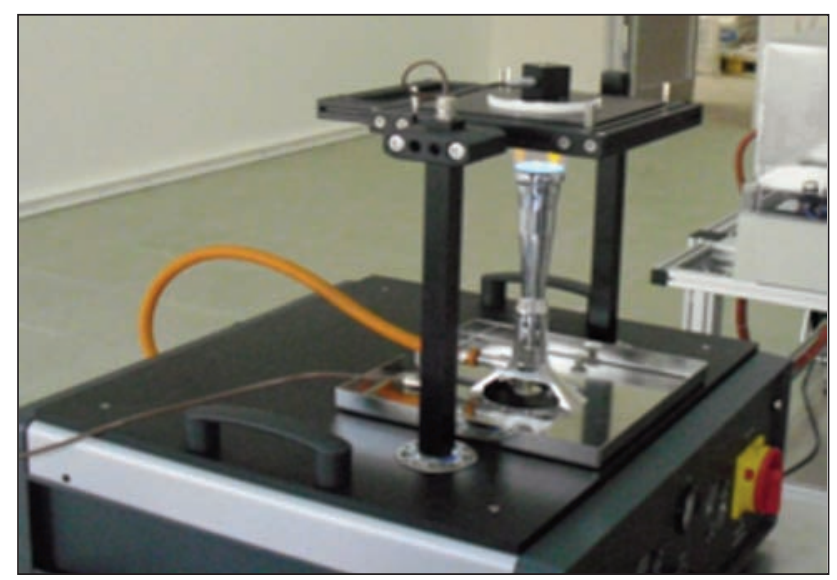

Fig. 1. Heat Transfer Flame tester

\section{Measurement of the radiant heat transfer (Heat transfer radiation)}

Radiant heat transfer can be assessed in accordance with Standards No. EN ISO 6942 "Protective clothing protection against heat and fire-Method of determining heat transmission on exposure to flame" [22]. The three-layered fabric is exposed to a radiant heat source of $40 \mathrm{~kW} / \mathrm{m}^{2}$. The time data to reach the temperature increase of $12^{\circ} \mathrm{C}$ or $24^{\circ} \mathrm{C}$ are recorded pursuant to EN 367 test method. They indicate the performance level of the three-layered fabrics, defined as Radiant Heat Transfer Index $\left(\mathrm{RHTI}_{12}, \mathrm{RHTI}_{24}\right)$. The heat transfer radiation tester used in the measurements is shown in figure 2.

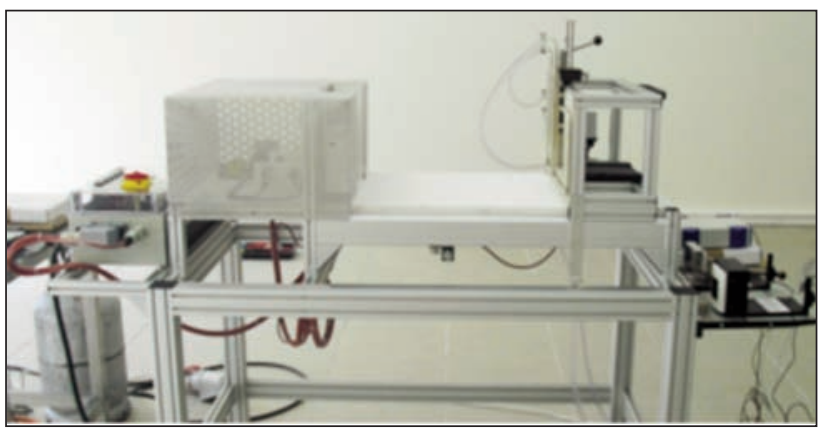

Fig. 2. Heat Transfer Radiation tester

The specifications of each fabric layer and the HTI and $\mathrm{RHTI}$ of the three layered fabric combinations are given in table 1.

\section{Artificial neural network (ANN)}

MLPNN can be defined as an important class of artificial neural networks, and they find different application areas in various disciplines. The network consists of three layers; input layer, one or more hidden layers and an output layer. Interconnection between the neurons of adjacent layers is provided by weights, and the information flow is in the forward direction from input to output. The input layer has no computation unit; the computation in the overall network takes place only at the hidden and the output layer neurons. The nonlinear mapping from input to output is obtained by weight adjustments through backpropagation algorithm [23]. The backpropagation algorithm aims to reduce the error between the original training output and the actual output. Neurons in the hidden and output layers perform a specific mathematical process, which is called activation function. The output from hidden layer functions goes to the input of adjacent layer neurons. The sigmoid activation function is the common function for most of the applications.

To apply to neural networks, the complete data set were divided into three parts: i) the training set, ii) the validation set, and iii) a test set. The training set is used to train the neural net to obtain a minimum error. The validation set is not used for training purpose. However, this data set provides performance analysis of the network during the training process. The decision to stop the learning is taken based on obtaining at the minimum of the validation set error. After completing the learning phase, the test data set is used to check the performance of the neural network.

In this study, MLPNNs were used to predict the thermal protective performance of three-layered fabrics of firefighter protective clothing from input fabric characteristics. The total of measured fabric parameters were 13. Due to the fact that the warp yarn and weft yarn numbers are equal, and therefore only one of them was used as the input value to ANN. The information of the weaving for Twill or Ripstop was converted into numerical data as 1 and 2, respectively. Finally, 12 input values were selected to train the networks. To find the best network performance, six different multilayer perceptron neural networks (MLPNN) with a single hidden layer were constructed using MATLAB to predict the convective heat transfer and the radiant heat transfer of three-layered fabric assemblies. The only difference among these networks was the number of outputs. Network 1 , and 2 produces single output for $\mathrm{HTI}_{12}$ and $\mathrm{HTI}_{24}$ of $\mathrm{EN} 367$ standard, respectively, and Network 3, and 4 produces single output for $\mathrm{RHTI}_{12}$ and $\mathrm{RHTI}_{24}$ of EN ISO 6942 standard, respectively. Whereas, Network 5, and 6 produces two outputs for $\mathrm{HTI}_{12}$ and $\mathrm{HTI}_{24}$ of EN 367 standard and for $\mathrm{RHTI}_{12}$ and $\mathrm{RHTI}_{24}$ of EN ISO 6942 standard, respectively. Warp count, weft count and their densities are included within the weight input of outer shell. In this consideration, all networks were also trained by exempting warp/weft count and their densities from the network input training set. However, theperformance of these networks was slightly lower than the networks with full input set training. Since previous related studies use the similar data sets, it was decided to use all 12 input date set. Figure 3 shows the block diagram of all networks. 


\begin{tabular}{|c|c|c|c|c|c|c|c|c|c|c|c|c|c|c|c|c|c|}
\hline \multirow[b]{3}{*}{$\begin{array}{l}\frac{0}{2} \\
\frac{0}{0} \\
\frac{0}{\tilde{E}} \\
\text { ஸे }\end{array}$} & \multicolumn{13}{|c|}{ INPUTS } & \multicolumn{4}{|c|}{ OUTPUTS } \\
\hline & \multicolumn{8}{|c|}{ Outer Shell (T: Twill, R: Ripstop) } & \multicolumn{3}{|c|}{ Moisture Barrier } & \multicolumn{2}{|c|}{ Thermal Liner } & \multirow[b]{2}{*}{ 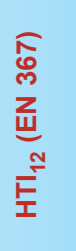 } & & & \\
\hline & 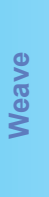 & 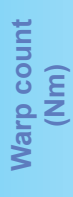 & 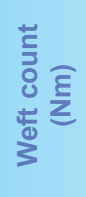 & 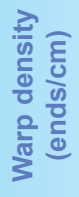 & 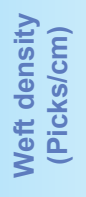 & 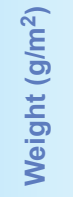 & 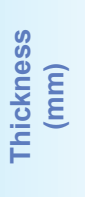 & $\frac{\overline{0}}{\overline{0}}$ & 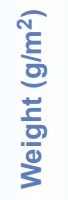 & 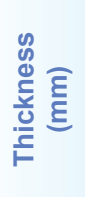 & 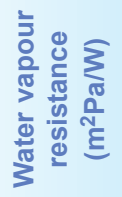 & 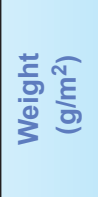 & 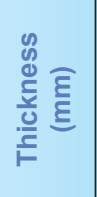 & & 点 & 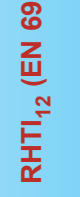 & 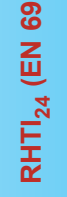 \\
\hline 1 & $\bar{T}$ & 55 & 55 & 26 & 24 & 195 & 0,47 & 27,04 & 85 & 0,15 & 7,4 & 270 & 2,9 & 10,4 & 14,5 & 14,7 & 20,2 \\
\hline 2 & $T$ & 55 & 55 & 26 & 24 & 195 & 0,47 & 27,04 & 85 & 0,15 & 7,4 & 240 & 1,24 & 10 & 13,7 & 12,9 & 18,7 \\
\hline 3 & $T$ & 55 & 55 & 26 & 24 & 195 & 0,47 & 27,04 & 85 & 0,15 & 7,4 & 205 & 1,23 & 9,6 & 13,1 & 10,2 & 14,8 \\
\hline 4 & $T$ & 55 & 55 & 26 & 24 & 195 & 0,47 & 27,04 & 85 & 0,15 & 7,4 & 260 & 3,24 & 9,8 & 13,4 & 15,4 & 22 \\
\hline 5 & $T$ & 55 & 55 & 26 & 24 & 195 & 0,47 & 27,04 & 145 & 0,31 & 10,7 & 270 & 2,9 & 12,9 & 17,2 & 15,5 & 21,9 \\
\hline 6 & $T$ & 55 & 55 & 26 & 24 & 195 & 0,47 & 27,04 & 145 & 0,31 & 10,7 & 240 & 1,24 & 11,4 & 15,9 & 14,9 & 22,2 \\
\hline 7 & $T$ & 55 & 55 & 26 & 24 & 195 & 0,47 & 27,04 & 145 & 0,31 & 10,7 & 205 & 1,23 & 9,5 & 12,9 & 12,1 & 16,9 \\
\hline 8 & $T$ & 55 & 55 & 26 & 24 & 195 & 0,47 & 27,04 & 145 & 0,31 & 10,7 & 260 & 3,24 & 11,1 & 14,6 & 15,3 & 22 \\
\hline 9 & $\bar{T}$ & 55 & 55 & 26 & 24 & 195 & 0,47 & 27,04 & 90 & 0,35 & 9,83 & 270 & 2,9 & 11,1 & 15,2 & 13,9 & 20,1 \\
\hline 10 & $T$ & 55 & 55 & 26 & 24 & 195 & 0,47 & 27,04 & 90 & 0,35 & 9,83 & 240 & 1,24 & 14,4 & 19,1 & 19,2 & 25,5 \\
\hline 11 & $T$ & 55 & 55 & 26 & 24 & 195 & 0,47 & 27,04 & 90 & 0,35 & 9,83 & 205 & 1,23 & 11,1 & 15,1 & 14,7 & 20,3 \\
\hline 12 & $T$ & 55 & 55 & 26 & 24 & 195 & 0,47 & 27,04 & 90 & 0,35 & 9,83 & 260 & 3,24 & 12,6 & 17,4 & 16,1 & 22,3 \\
\hline 13 & $T$ & 55 & 55 & 26 & 24 & 195 & 0,47 & 27,04 & 125 & 0,89 & 13,025 & 270 & 2,9 & 14,7 & 20,8 & 18,1 & 24,7 \\
\hline 14 & $T$ & 55 & 55 & 26 & 24 & 195 & 0,47 & 27,04 & 125 & 0,89 & 13,025 & 240 & 1,24 & 12,9 & 17,6 & 17,5 & 24,4 \\
\hline 15 & $T$ & 55 & 55 & 26 & 24 & 195 & 0,47 & 27,04 & 125 & 0,89 & 13,025 & 205 & 1,23 & 12,4 & 16,7 & 14,2 & 20,2 \\
\hline 16 & $T$ & 55 & 55 & 26 & 24 & 195 & 0,47 & 27,04 & 125 & 0,89 & 13,025 & 260 & 3,24 & 14,7 & 20,2 & 18,4 & 25 \\
\hline 17 & $R$ & 55 & 55 & 26 & 24 & 195 & 0,46 & 27,04 & 85 & 0,15 & 7,4 & 270 & 2,9 & 9,9 & 13,7 & 13,2 & 18,5 \\
\hline 18 & $\mathrm{R}$ & 55 & 55 & 26 & 24 & 195 & 0,46 & 27,04 & 85 & 0,15 & 7,4 & 240 & 1,24 & 10,5 & 14,6 & 13,6 & 19,9 \\
\hline 19 & $\mathrm{R}$ & 55 & 55 & 26 & 24 & 195 & 0,46 & 27,04 & 85 & 0,15 & 7,4 & 205 & 1,23 & 9,6 & 13,2 & 10,8 & 15,8 \\
\hline 20 & $\mathrm{R}$ & 55 & 55 & 26 & 24 & 195 & 0,46 & 27,04 & 85 & 0,15 & 7,4 & 260 & 3,24 & 11,1 & 15,5 & 15,3 & 21,3 \\
\hline 21 & $\bar{R}$ & 55 & 55 & 26 & 24 & 195 & 0,46 & 27,04 & 145 & 0,31 & 10,7 & 270 & 2,9 & 11,7 & 15,8 & 14,3 & 19,9 \\
\hline 22 & $\mathrm{R}$ & 55 & 55 & 26 & 24 & 195 & 0,46 & 27,04 & 145 & 0,31 & 10,7 & 240 & 1,24 & 13,9 & 19,9 & 15,6 & 23,2 \\
\hline 23 & $\mathrm{R}$ & 55 & 55 & 26 & 24 & 195 & 0,46 & 27,04 & 145 & 0,31 & 10,7 & 205 & 1,23 & 11,1 & 15,4 & 12,5 & 18 \\
\hline 24 & $\mathrm{R}$ & 55 & 55 & 26 & 24 & 195 & 0,46 & 27,04 & 145 & 0,31 & 10,7 & 260 & 3,24 & 13 & 18,1 & 15 & 22,5 \\
\hline 25 & $\mathrm{R}$ & 55 & 55 & 26 & 24 & 195 & 0,46 & 27,04 & 90 & 0,35 & 9,83 & 270 & 2,9 & 11,7 & 16,1 & 13,2 & 18,5 \\
\hline 26 & $\mathrm{R}$ & 55 & 55 & 26 & 24 & 195 & 0,46 & 27,04 & 90 & 0,35 & 9,83 & 240 & 1,24 & 13,1 & 17,8 & 16,3 & 22,1 \\
\hline 27 & $\mathrm{R}$ & 55 & 55 & 26 & 24 & 195 & 0,46 & 27,04 & 90 & 0,35 & 9,83 & 205 & 1,23 & 10,8 & 14,8 & 12,2 & 18,1 \\
\hline 28 & $R$ & 55 & 55 & 26 & 24 & 195 & 0,46 & 27,04 & 90 & 0,35 & 9,83 & 260 & 3,24 & 13,3 & 18,5 & 16,4 & 22,2 \\
\hline 29 & $\mathrm{R}$ & 55 & 55 & 26 & 24 & 195 & 0,46 & 27,04 & 125 & 0,89 & 13,025 & 270 & 2,9 & 13,4 & 18,3 & 17,2 & 23,6 \\
\hline 30 & $\mathrm{R}$ & 55 & 55 & 26 & 24 & 195 & 0,46 & 27,04 & 125 & 0,89 & 13,025 & 240 & 1,24 & 13,9 & 19,3 & 17,8 & 25,3 \\
\hline 31 & $\mathrm{R}$ & 55 & 55 & 26 & 24 & 195 & 0,46 & 27,04 & 125 & 0,89 & 13,025 & 205 & 1,23 & 13 & 17,7 & 15,8 & 23,2 \\
\hline 32 & $\mathrm{R}$ & 55 & 55 & 26 & 24 & 195 & 0,46 & 27,04 & 125 & 0,89 & 13,025 & 260 & 3,24 & 14,6 & 19,9 & 18,8 & 25,6 \\
\hline 33 & $\mathrm{R}$ & 26 & 26 & 21 & 18 & 200 & 0,57 & 444,4 & 85 & 0,15 & 7,4 & 270 & 2,9 & 11,1 & 15,4 & 15,7 & 23,9 \\
\hline 34 & $\mathrm{R}$ & 26 & 26 & 21 & 18 & 200 & 0,57 & 44,4 & 85 & 0,15 & 7,4 & 240 & 1,24 & 10,9 & 15,2 & 15,3 & 23,5 \\
\hline 35 & $\mathrm{R}$ & 26 & 26 & 21 & 18 & 200 & 0,57 & 44,4 & 85 & 0,15 & 7,4 & 205 & 1,23 & 9,8 & 13,4 & 13,3 & 20,5 \\
\hline 36 & $\mathrm{R}$ & 26 & 26 & 21 & 18 & 200 & 0,57 & 44,4 & 85 & 0,15 & 7,4 & 260 & 3,24 & 11,9 & 16,9 & 17 & 24,9 \\
\hline 37 & $\mathrm{R}$ & 26 & 26 & 21 & 18 & 200 & 0,57 & 44,4 & 145 & 0,31 & 10,7 & 270 & 2,9 & 11,2 & 15,8 & 16,9 & 24 \\
\hline 38 & $\mathrm{R}$ & 26 & 26 & 21 & 18 & 200 & 0,57 & 44,4 & 145 & 0,31 & 10,7 & 240 & 1,24 & 12,7 & 17,5 & 16,3 & 24,2 \\
\hline 39 & $\mathrm{R}$ & 26 & 26 & 21 & 18 & 200 & 0,57 & 44,4 & 145 & 0,31 & 10,7 & 205 & 1,23 & 11,1 & 15,6 & 14,5 & 21,3 \\
\hline 40 & $\mathrm{R}$ & 26 & 26 & 21 & 18 & 200 & 0,57 & 44,4 & 145 & 0,31 & 10,7 & 260 & 3,24 & 14 & 19,6 & 18,7 & 27,7 \\
\hline 41 & $\mathrm{R}$ & 26 & 26 & 21 & 18 & 200 & 0,57 & 44,4 & 90 & 0,35 & 9,83 & 270 & 2,9 & 13,8 & 20 & 20,2 & 29,6 \\
\hline 42 & $\mathrm{R}$ & 26 & 26 & 21 & 18 & 200 & 0,57 & 44,4 & 90 & 0,35 & 9,83 & 240 & 1,24 & 10 & 14,9 & 21,6 & 31,0 \\
\hline 43 & $\mathrm{R}$ & 26 & 26 & 21 & 18 & 200 & 0,57 & 44,4 & 90 & 0,35 & 9,83 & 205 & 1,23 & 10,9 & 14,9 & 15,7 & 23,3 \\
\hline 44 & $R$ & 26 & 26 & 21 & 18 & 200 & 0,57 & 44,4 & 90 & 0,35 & 9,83 & 260 & 3,24 & 13,4 & 18,9 & 20 & 29 \\
\hline 45 & $\mathrm{R}$ & 26 & 26 & 21 & 18 & 200 & 0,57 & 44,4 & 125 & 0,89 & 13,025 & 270 & 2,9 & 15,6 & 22 & 20,9 & 31 \\
\hline 46 & $\mathrm{R}$ & 26 & 26 & 21 & 18 & 200 & 0,57 & 44,4 & 125 & 0,89 & 13,025 & 240 & 1,24 & 14,1 & 19,5 & 17,6 & 27,1 \\
\hline 47 & $\mathrm{R}$ & 26 & 26 & 21 & 18 & 200 & 0,57 & 44,4 & 125 & 0,89 & 13,025 & 205 & 1,23 & 12,5 & 17,1 & 16,4 & 24,9 \\
\hline 48 & $\mathrm{R}$ & 26 & 26 & 21 & 18 & 200 & 0,57 & 44,4 & 125 & 0,89 & 13,025 & 260 & 3,24 & 14,4 & 20,3 & 20,6 & 30,2 \\
\hline 49 & $T$ & 64 & 64 & 30 & 22 & 165 & 0,32 & 33,75 & 85 & 0,15 & 7,4 & 270 & 2,9 & 12,8 & 18,4 & 16,4 & 24,2 \\
\hline 50 & $T$ & 64 & 64 & 30 & 22 & 165 & 0,32 & 33,75 & 85 & 0,15 & 7,4 & 240 & 1,24 & 11,5 & 15,9 & 13,5 & 20,5 \\
\hline 51 & $T$ & 64 & 64 & 30 & 22 & 165 & 0,32 & 33,75 & 85 & 0,15 & 7,4 & 205 & 1,23 & 10,4 & 14,4 & 11,9 & 18,3 \\
\hline 52 & $T$ & 64 & 64 & 30 & 22 & 165 & 0,32 & 33,75 & 85 & 0,15 & 7,4 & 260 & 3,24 & 12,6 & 17,9 & 15,6 & 22,8 \\
\hline 53 & $T$ & 64 & 64 & 30 & 22 & 165 & 0,32 & 33,75 & 145 & 0,31 & 10,7 & 270 & 2,9 & 14,4 & 20,8 & 19,2 & 27,8 \\
\hline 54 & $T$ & 64 & 64 & 30 & 22 & 165 & 0,32 & 33,75 & 145 & 0,31 & 10,7 & 240 & 1,24 & 12,8 & 17,8 & 15,1 & 22,4 \\
\hline 55 & $T$ & 64 & 64 & 30 & 22 & 165 & 0,32 & 33,75 & 145 & 0,31 & 10,7 & 205 & 1,23 & 11,8 & 16,2 & 14,4 & 21,2 \\
\hline 56 & $T$ & 64 & 64 & 30 & 22 & 165 & 0,32 & 33,75 & 145 & 0,31 & 10,7 & 260 & 3,24 & 15,3 & 21,5 & 19,9 & 28,1 \\
\hline 57 & $T$ & 64 & 64 & 30 & 22 & 165 & 0,32 & 33,75 & 90 & 0,35 & 9,83 & 270 & 2,9 & 15 & 21,6 & 18,3 & 26,1 \\
\hline 58 & $T$ & 64 & 64 & 30 & 22 & 165 & 0,32 & 33,75 & 90 & 0,35 & 9,83 & 240 & 1,24 & 12,9 & 17,9 & 15,8 & 22,9 \\
\hline 59 & $T$ & 64 & 64 & 30 & 22 & 165 & 0,32 & 33,75 & 90 & 0,35 & 9,83 & 205 & 1,23 & 11,8 & 16,1 & 14,3 & 21,3 \\
\hline 60 & $T$ & 64 & 64 & 30 & 22 & 165 & 0,32 & 33,75 & 90 & 0,35 & 9,83 & 260 & 3,24 & 14,7 & 20,2 & 19,5 & 26,6 \\
\hline 61 & $T$ & 64 & 64 & 30 & 22 & 165 & 0,32 & 33,75 & 125 & 0,89 & 13,025 & 270 & 2,9 & 14,8 & 21,3 & 19,3 & 27,1 \\
\hline 62 & $T$ & 64 & 64 & 30 & 22 & 165 & 0,32 & 33,75 & 125 & 0,89 & 13,025 & 240 & 1,24 & 14,1 & 19,7 & 17,7 & 25,3 \\
\hline 63 & $T$ & 64 & 64 & 30 & 22 & 165 & 0,32 & 33,75 & 125 & 0,89 & 13,025 & 205 & 1,23 & 12,2 & 16,3 & 15,4 & 22,9 \\
\hline
\end{tabular}




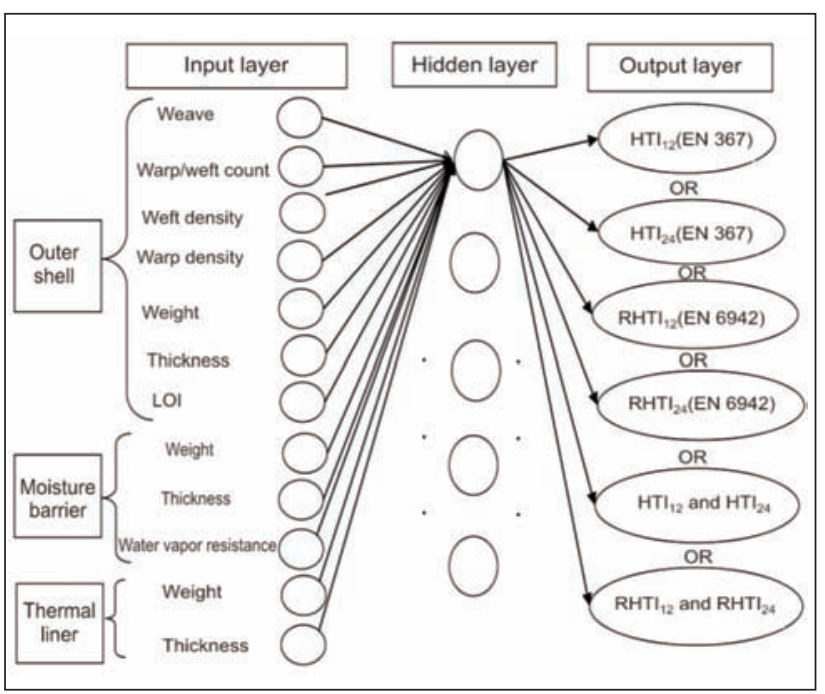

Fig. 3. Block diagram of the networks

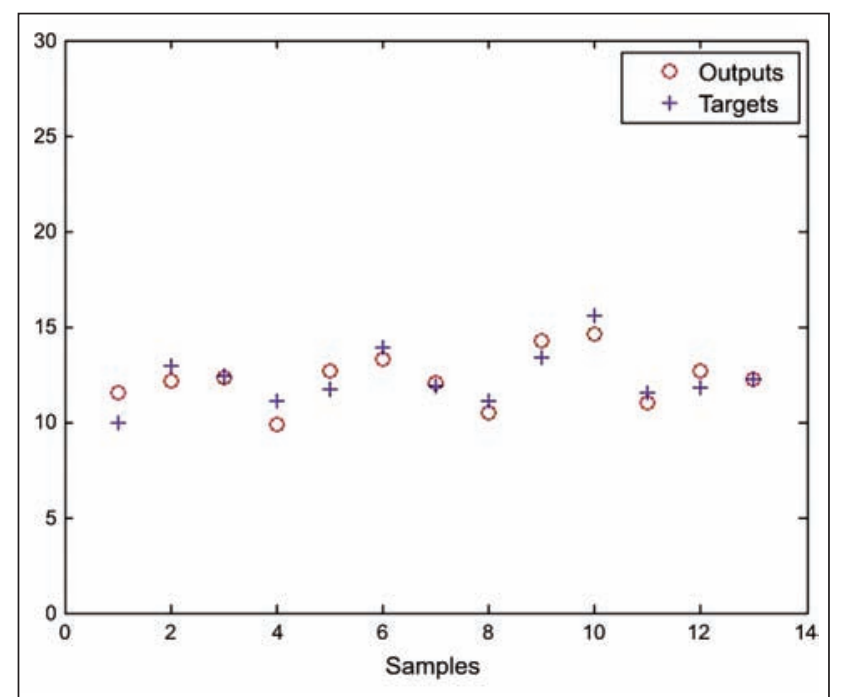

Fig. 4. Comparison between predicted and test sample values for $\mathrm{HTI}_{12}$ of EN 367 standard

\section{RESULTS AND DISCUSSION}

There are total of 64 data sets, each of which consists of 12 input and 4 outputs. 7 inputs were obtained from the outer shell, 3 inputs from the moisture barrier, and the other 2 from the thermal liner. The outputs are $\mathrm{HTI}_{12}$ and $\mathrm{HTI}_{24}$ for EN 367 standard and $\mathrm{RHTI}_{12}$ and $\mathrm{RHTI}_{24}$ for EN ISO 6942 standard.

In this study, all six networks were trained with a different number of hidden layers and neurons in each layer. The best performance was empirically obtained with only one hidden layer having five neurons. Neural networks were trained with LevenbergMarquardt backpropogation algorithm, which is generally considered the fastest algorithm for providing optimized weight and bias values. Data sets were randomly divided into three sections: $70 \%$ for training, $10 \%$ for validation, and the remaining $20 \%$ to test the networks. To obtain comparable results, all networks were trained and tested with the same data sets.

Network 1 and Network 2, which had only one output, were trained to predict $\mathrm{HTI}_{12}$ and $\mathrm{HTI}_{24}$ for EN 367 standard, respectively, while Network 3 and 4, which also had only one output, were trained to predict $\mathrm{RHTI}_{12}$ and $\mathrm{RHTI}_{24}$ for EN ISO 6942 standard. In contrast, Network 5 and 6 were trained to predict two outputs for $\mathrm{HTI}_{12}$ and $\mathrm{HTI}_{24}$ of EN 367 standard and for $\mathrm{RHTI}_{12}$ and $\mathrm{RHTI}_{24}$ of EN ISO 6942 standard, respectively. The obtained network output values and the measured target sample values are illustrated in figures $4,5,6,7,8$, and 9 , which all show that there are good approximations between network output and corresponding measured target values.

Neural networks were compared with each other by calculating mean absolute percent error (MAPE) between target and predicted values of networks. MAPE is calculated as the average of the unsigned percentage error using the following formula in equation 1. Normally, absolute value of target values,

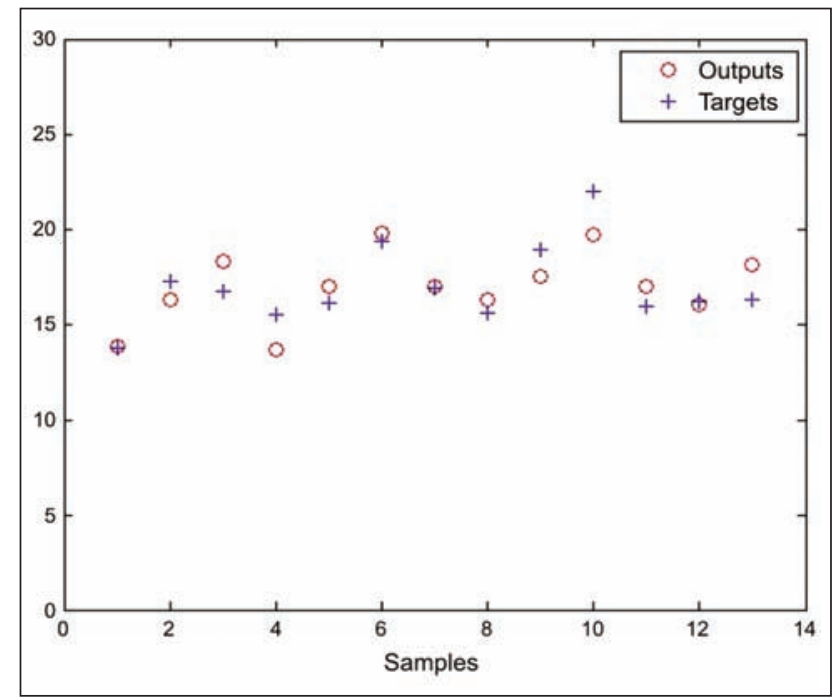

Fig. 5. Comparison between predicted and test sample values for $\mathrm{HTI}_{24}$ of EN 367 standard

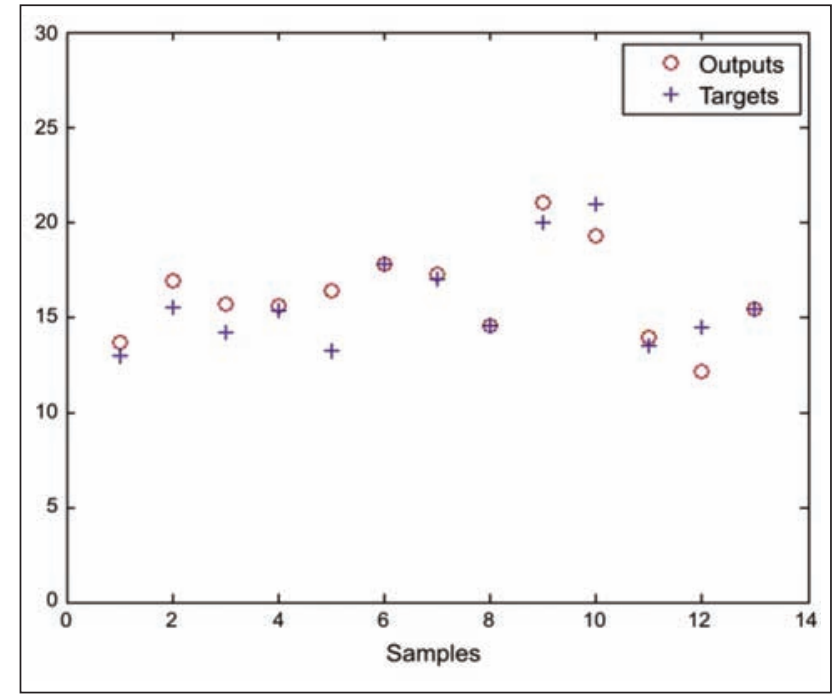

Fig. 6. Comparison between predicted and test sample values for $\mathrm{RHTI}_{12}$ of EN ISO 6942 standard 


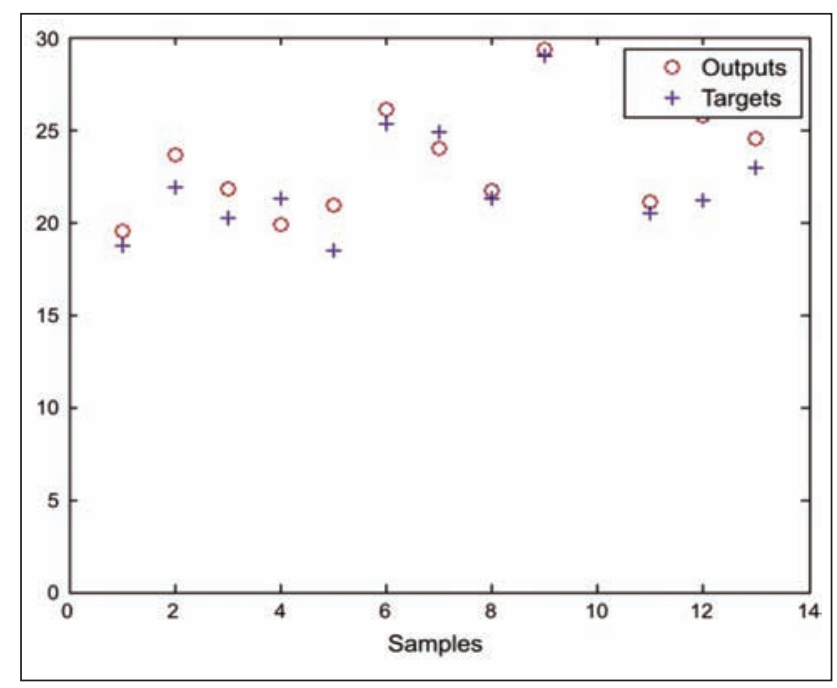

Fig. 7. Comparison between predicted and test sample values for $\mathrm{RHTI}_{24}$ of EN ISO 6942 standard

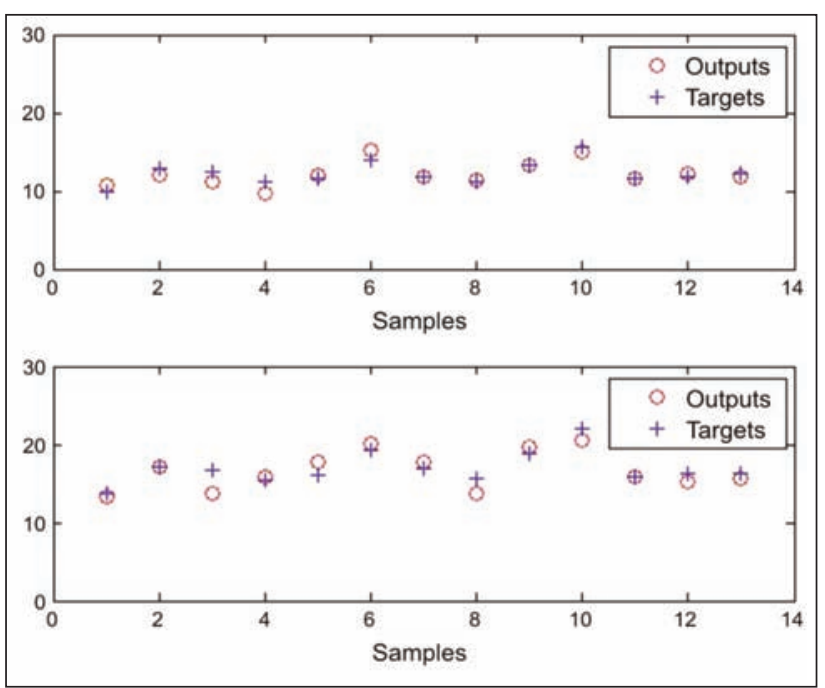

Fig. 8. Comparison between predicted and test sample values for $\mathrm{HTI}_{12}$ and $\mathrm{HTI}_{24}$ of EN 367standard, respectively

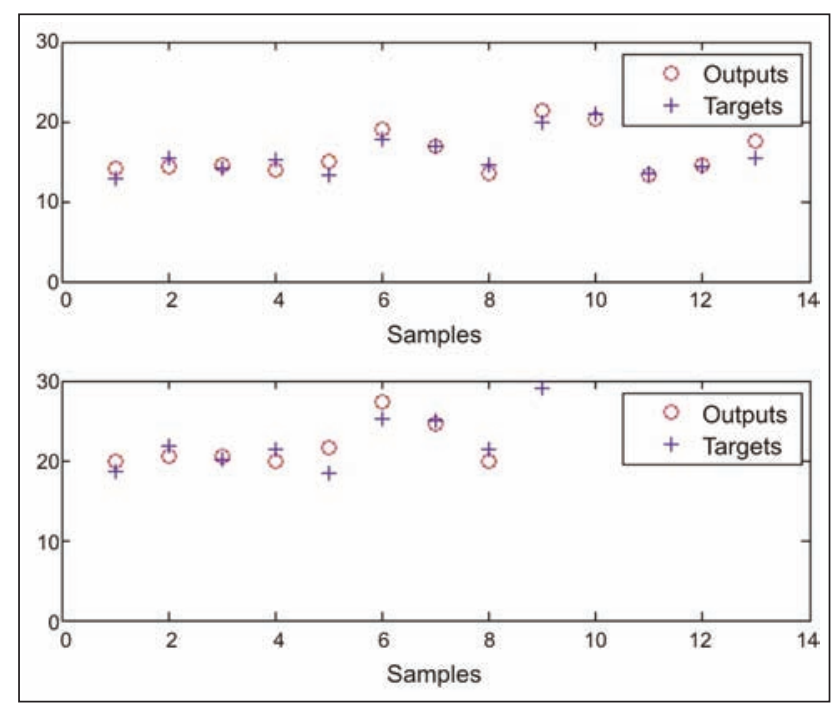

Fig. 9. Comparison between predicted and test sample values for $\mathrm{RHTI}_{12}$ and $\mathrm{RHTI}_{24}$ of EN ISO 6942 standard, respectively which is given in the denominator of the equation, is taken. However, the absolute value is not taken here as target value is always positive.

MAPE $=\frac{\mid \text { target value }- \text { predicted value } \mid}{\text { target value }} \times \frac{100 \%}{n}$

where $n$ is total number of samples. Table 2 gives the calculated MAPE values and correlation coefficient of all six networks. Networks 1, 2, 3, and 4 provide single output and Networks 5 and 6 gives two outputs. Therefore, MAPE and correlation coefficient values of last two networks are based on the average of two outputs. From table 2, it is seen that error values of all networks are similar, and the obtained error values varies between $4.95 \%$ and $6.87 \%$. However, the networks trained with data obtained in accordance with EN 367 standard provides slightly better error values compared to the networks trained with data obtained in respect to EN ISO 6942 standard. The other outcome of these comparisons is the better result of Network 5 and Network 6 compared to other four networks. The result suggests that prediction of two rather than one output provides less error within the same standard. One possible explanation for this performance improvement would be the reduction of similarities between the output data sets. The consistency of performance of network with two outputs was verified by Networks 5 and 6 . In particular, Network 5 gives the best performance among all six networks. The correlation coefficient of target and predicted values gives the strength and direction of the linear relationship. While the correlation coefficients for Network 1 to 4 are similar, Network 5 and Network 6 provide slightly higher values. These results also support lower error values of Network 5 and Network 6.

\begin{tabular}{|l|c|c|c|}
\hline \multicolumn{1}{|c|}{ Table 2 } \\
\hline Networks & MAPE & $\begin{array}{c}\text { Correlation } \\
\text { coefficient }\end{array}$ & Description \\
\hline Network 1 & $5.94 \%$ & 0.83 & $\begin{array}{c}\mathrm{HTI}_{12} \\
\text { of EN 367 standard }\end{array}$ \\
\hline Network 2 & $5.40 \%$ & 0.86 & $\begin{array}{c}\mathrm{HTI}_{24} \\
\text { of EN 367 standard }\end{array}$ \\
\hline Network 3 & $6.87 \%$ & 0.84 & $\begin{array}{c}\mathrm{RHTI} \\
\text { ISO } 6942 \text { standard }\end{array}$ \\
\hline Network 4 & $6.46 \%$ & 0.88 & $\begin{array}{c}\mathrm{RHTI} \\
\text { ISO } 6942 \text { standard }\end{array}$ \\
\hline Network 5 & $4.95 \%$ & 0.94 & $\begin{array}{c}\mathrm{HTI}_{12}+\mathrm{HTI}_{24} \\
\text { of EN 367 standard }\end{array}$ \\
\hline Network 6 & $6.23 \%$ & 0.92 & $\begin{array}{c}\mathrm{RHTI} \\
\text { of EN ISO } 6942 \\
\text { standard }\end{array}$ \\
\hline
\end{tabular}

\section{CONCLUSIONS}

In this study, six different artificial neural networks were studied using MATLAB to predict the convective heat transfer index and radiant heat transfer index of 
three-layered fabrics for firefighter protective clothing. Four neural networks; Network 1 to 4 were constructed with 12 inputs data and only one output, corresponding to the index of either convective or radiant heat transfer. Whereas, the Networks 5 and Network 6 were constructed with 12 inputs and two outputs, one for convective heat transfer and one for radiant heat transfer. All networks have one hidden layer with 5 neurons.

The simulation results have shown that all six networks gives similar prediction error values for the corresponding experimentally obtained indexes of convective heat transfer or radiant heat transfer. The results reveal that predicting two rather than one output gave a slight advantage. This performance improvement could possibly the reduction of similarities between two outputs in respect to one output. Moreover, network outputs trained with indexes of convective heat transfer gives less error values independent of number of outputs. The best performance was obtained by Network 5, trained to predict $\mathrm{HTI}_{12}$ and $\mathrm{HTI}_{24}$ of EN 367 standard.

\section{ACKNOWLEDGEMENTS}

This study was funded by Turkish Ministry of Science and Technology SANTEZ (grant number 00782.STZ.2011-1).

\section{BIBLIOGRAPHY}

[1] Mandal, S., Song, G., Ackerman, M., Paskaluk, S. and Gholamreza, F. Characterization of textile fabrics under various thermal exposures, In: Textile Research Journal, 2013, vol. 83, no. 10, pp. 1005-1019.

[2] Fu, M., Weng, W., Yuan, H. Effects of multiple air gaps on the thermal performance of firefighter protective clothing under low-level heat exposure, In: Textile Research Journal, 2013, vol. 84, no. 9, pp. 968-978.

[3] Song, G., Cao, W., Gholamreza, F. Analyzing stored thermal energy and thermal protective performance of clothing. In: Textile Research Journal, 2011, vol. 81, no. 11, pp. 1124-1138.

[4] Song, G., Paskaluk, S., Sati, R., Crown, E. M., Dale, J. D., Ackerman, M. Thermal protective performance of protective clothing used for low radiant heat protection. In: Textile Research Journal, 2011, vol. 81, no. 3, pp. 311-323.

[5] Kutlu, B. and Cireli, A. Thermal analysis and performance properties of thermal protective clothing. In: Fibres \& Textiles in Eastern Europe, 2005, vol. 13, no. 3, pp. 58-62.

[6] Sun, G., Yoo, H. S., Zhang, X. S., Pan, N. Radiant protective and transport properties of fabrics used by wild land fire fighters, IN: Textile Research Journal, 2000, vol. 70, no. 7, pp. 567-573.

[7] Rossi, R. M., Bolli, W., Staempfli, R. Performance of firefighters' protective clothing after heat exposure, In: International Journal of Occupational Safety and Ergonomics (JOSE), 2008, vol. 14, no. 1, pp. 55-60.

[8] Adya, M., Collopy, F. How effective are neural networks at forecasting and prediction? A review and evaluation, In: Journal of Forecasting, 1998, vol. 17, pp. 481-495.

[9] Tehran, M. A., Maleki, M. Artificial neural network prosperities in textile applications, In: Artificial neural networks Industrial and Control Engineering Applications, Rijeka, Croatia, InTech, 2011, pp. 35-64.

[10] Gong, R. H., Chen, Y. Predicting the performance of fabrics in garment manufacturing with artificial neural Networks, In: Textile Research Journal, 1999, vol. 69, no. 7, pp. 477-482.

[11] Kumar, A. Neural network based detection of local textile defects, In: Pattern Recognition, 2003, vol. 36, no. 7, pp. 1645-1659.

[12] Behera, B. K., Mani, M. P. Characterization and classification of fabric defects using discrete cosine transformation and artificial neural network, In: Indian Journal of Fibre \& Textile Research, 2007, vol. 32, no. 4, pp. 421-426.

[13] Chattopadhyay, R., Guha, A. Artificial neural networks: Applications to textiles, In: Textile Progress, 2004, vol. 35, no. 1, pp. 1-46.

[14] Guha, A., Chattopadhyay, R., Jayadeva, Predicting yarn tenacity: A Comparison of mechanistic, statistical, and neural network models, In: Journal of the Textile Institute, 2001, vol. 92, no. 2, pp. 139-145.

[15] Fayala, F., Alibi, H., Benltoufa, S., Jemni, A. Neural Network for predicting thermal conductivity of knit materials, In: Journal of Engineered Fibers and Fabrics, 2008, vol. 3, no. 4, pp. 53-60.

[16] Matusiak, M. Application of artificial neural networks to predict the air permeability of woven fabrics, In: Fıbres \& Textıles in Eastern Europe, 2015, vol. 23, no. 1(109), pp. 41-48.

[17] Jhani, Y., Kothari, V. K., Gupta, D. Development and comparison of artificial neural network and statistical model for prediction of thermo-physiological properties of polyester-cotton plated fabrics, In: Fashion and Textiles, 2016, vol. 3, no. 19, pp. 1-16.

[18] Bhattacharjee, D., Kothari, V. K. A neural network system for prediction of thermal resistance of textile fabrics, In: Textile Research Journal, 2007, vol. 77, no. 1, pp. 4-12.

[19] Cui, Z., Zhang, W. An adaptive neural network system for prediction of thermal protective performance of fabrics, In: 3rd International Conference on Intelligent System and Knowledge Engineering, 2008, pp. 837-841.

[20] European Committee for Standardization (CEN). Protective clothing-protection against heat and fire-method of determining heat transmission on exposure to flame (Standard No. EN 367:1992). Brussels, Belgium: CEN; 1992. 
[21] Scott, R. A. Textiles for Protection, 1st edition. Cambridge, Woodhead Publishing Limited, 2005.

[22] International Organization for Standardization (ISO). Protective clothing-protection against heat and fire-method of test: evaluation of materials and material assemblies when exposed to a source of radiant heat (Standard No. ISO 6942:2002). Geneva, Switzerland: ISO; 2002.

[23] Haykin, S., Neural network: A Comprehensive foundation, Second ed. (prentice hall, New Jersey, USA, 1999.

\section{Authors:}

MÜGE DURSUN ${ }^{1}$, YAVUZ ŞENOL ${ }^{2}$, ENDER YAZGAN BULGUN ${ }^{3}$, TANER AKKAN ${ }^{4}$

${ }^{1}$ Dokuz Eylul University, Faculty of Engineering, Department of Textile Engineering, Tınaztepe Campus, 35390, Buca, Izmir, Turkey

2Dokuz Eylul University, Department of Electrical and Electronics Engineering, Tınaztepe Campus, 35390, Buca, Izmir, Turkey,

${ }^{3}$ Izmir University of Economics, Faculty of Fine Arts and Design, Department of Fashion and Textile Design, 35330, Balçova, Izmir, Turkey,

${ }^{4}$ Dokuz Eylul University, Izmir Vocational School, Department of Mechatronics, 35380, Buca, Izmir, Turkey,

e-mail: muge5678@gmail.com; yavuz.senol@deu.edu.tr; ender.bulgun@ieu.edu.tr; taner.akkan@deu.edu.tr

Corresponding author:

YAVUZ ŞENOL

e-mail: yavuz.senol@deu.edu.tr 